\title{
Safety and Immunogenicity of ETHIORAB Rabies Vaccine
}

Birhanu Hurisa', Belete Tegbaru', Dagmar Nolkes4, Abebe Mengesha', Gezahegn Kebede'1, Sisay Kerga', Amdemicael Adhanom ${ }^{1}$, Alemayehu Godana ${ }^{1}$, Dereje Nigussie ${ }^{1}$, Bethelehem Newayesilasie ${ }^{1}$, Gashaw Gebrewold ${ }^{1}$, Denis Bankovskiy ${ }^{2}$, Artem Metlin ${ }^{3}$ and Kelbessa Urga ${ }^{1 *}$

${ }^{1}$ Ethiopian Health and Nutrition Research Institute, Addis Abeba, Ethiopia

${ }^{2}$ Pokrov Plant of Biologics, Russian Federation, Russia

${ }^{3}$ Federal Centre for Animal Health, Russian Federation, Russia

${ }^{4}$ Haramaya University, Harer, Ethiopia not Russia

\begin{abstract}
Worldwide rabies in dogs is the source of $99 \%$ of human infections. This makes dogs potential reservoir and transmitters to human being. Pre and post-exposure prophylaxis are means of protection against the rabies virus. The main objective of this experiment was to determine the safety and immunogenicity of Vero cell culture based rabies vaccine "ETHIORAB" manufactured by Ethiopian Health and Nutrition Research Institute, Vaccine and Diagnostic Production Directorate. The obtained vaccine was tested on mice and satisfactory safety results were observed. Random Clinical Trial (RCT) design was used for this experiment. Twelve experimental dogs from local breed were duly conditioned during a quarantine period and assigned to two groups randomly. Group I (cases) were vaccinated subcutaneously with $1 \mathrm{ml}$ of ETHIORAB. Dogs in group II served as non-vaccinated controls. To evaluate the titer of the rabies virus neutralizing antibodies (VNA), sera were analyzed by Fluorescent Antibody Virus Neutralization (FAVN) test. Serum neutralizing antibody geomtric mean titers (GMT) to rabies virus was determined at days 7,15 , $21,30,60$ and 90 . Geomtric mean titers were equal to $1.55,1.73,2.02,3.45,3.57$ and $3.17 \mathrm{lU} / \mathrm{ml}$ respectively. All dogs showed VNA titers higher than the $0.5 \mathrm{IU} / \mathrm{ml}$ mandated $\mathrm{WHO}$ recommended threshold. This study indicated $E T H I O R A B$ rabies vaccine manufactured in Ethiopia is safe and immunogenic.
\end{abstract}

Keywords: Dogs; ETHIORAB; Immunogenicity; Safety; Titer

\section{Introduction}

Rabies is acute progressive fatal encephalitis, caused by RNA virus from the family Rhabdoviridae, genus Lyssavirus, which includes seven genotypes [1]. Although a number of carnivore and bat species serve as natural reservoirs, worldwide rabies in dogs is the source of $99 \%$ of human infections and poses a threat to $>3.3$ billion people [2]. There are an estimated 60,000 human rabies related deaths worldwide each year. Of these, most cases occur in Asia and Africa (WHO, 2009).

Rabies in Ethiopia is primarily a disease of dogs. Many people are at increased risk of being exposed to rabies since, man-dog contact is very common [3]. Annual reports of Ethiopian Health and Nutrition Research Institute (EHNRI) indicated that a total of 488 lab confirmed human rabies cases in and around Addis Abeba had occurred between the period 1964 and $1975[4,5]$. The total fatal human cases between 2001-2009 were 386 humans with annual range of 35 to 58 [4].

More than $95 \%$ of human rabies cases occur in unvaccinated or improperly treated individuals. This is at least partly due to the fact that modern post-exposure rabies prophylaxis is expensive and therefore not readily available in many endemic regions [6].

Vaccine immunogenicity is a key factor in judging the effectiveness of vaccines and usually reflects both the antigen content of a particular batch and the titer of antibody induced following inoculation. The key parameter measured in humans or animals, is the titer of neutralizing antibody induced following vaccination [7].

Rabies vaccines produced in mammalian neural tissues have the disadvantage of causing severe adverse reactions, at a rate estimated as 0.3-0.8 per thousand treated patients [8]. World Health Organization (WHO) has recommended since the 90s that they have to be replaced by vaccines produced in substrates free from animal nervous tissues, as the latter are more immunogenic and, more importantly, safer $[9,10]$. The vaccines recommended by WHO include those produced in Vero cells, available since the 1980 s. Unfortunately, the cell culture rabies vaccines are expensive and not readily available to individuals living in developing countries where rabies is endemic in dogs [11].

Sheep brain derived Fermi type rabies vaccine is still being manufactured and utilized for the majority of exposed patients in Ethiopia, even though this vaccine has been discouraged by the WHO. The high costs of tissue culture vaccine and inertia have been the main barrier to the replacement of Fermi type vaccine. Currently EHNRI is working to improve anti-rabies vaccine production by changing the nervous tissue vaccine (Fermi type) to cell culture based vaccine.

ETHIORAB is based on the Evelyn RokitnikiAbelseth (ERA) fixed rabies virus strain and propagated on Vero cell line. It is intended for use in medical practice for prophylactic vaccination of animals against rabies. It is inactivated with $5 \%$ formalin and it is in liquid form.

Special attention must be paid to testing the safety and immunogenicity of inactivated vaccines [12]. An important factor in the preparation of a viral vaccine is that the immunogenicity of the virus be retained at the highest possible level. Achieving this goal, while ensuring the complete inactivation of the virus, quite often presents a technical problem [13].

The development of adequate level of antibody $\geq 0.5 \mathrm{IU} / \mathrm{ml}$ is necessary for protection against rabies. In contrast to the nerve

*Corresponding author: Birhanu Hurisa, Ethiopian Health and Nutrition Research Institute, Vaccine and Diagnostic Production Directorate, P.O.Box 1242, Addis Abeba, Ethiopia, Tel:+251112134032/+251913229849; E-mail: birhanuh@ehnri. gov.et, bhurrish@yahoo.com

Received June 26, 2013; Accepted July 20, 2013; Published July 25, 2013

Citation: Hurisa B, Tegbaru B, Nolkes D, Mengesha A, Kebede G, et al. (2013) Safety and Immunogenicity of ETHIORAB Rabies Vaccine. J Vaccines Vaccin 4: 195. doi: $10.4172 / 2157-7560.1000195$

Copyright: $\odot 2013$ Hurisa B, et al. This is an open-access article distributed under the terms of the Creative Commons Attribution License, which permits unrestricted use, distribution, and reproduction in any medium, provided the original author and source are credited. 
tissue vaccines, tissue culture vaccines particularly human diploidcell strain type is highly potent, immunogenic and least reactogenic [14]. According to the WHO, Biological standardizations [15], rabies vaccine passes the test if the estimated immunogenicity is not less than $0.5 \mathrm{IU} / \mathrm{ml}$. In addition, the final vaccine should not be licensed or released unless an adequately designed experiment has demonstrated a duration of immunity of at least 1 year in the species for which the vaccine is to be used [12]. There have been no studies of safety and immune response to $E T H I O R A B$ anti-rabies vaccine produced in Ethiopia. In order to demonstrate that $E T H I O R A B$ is safe and effective, this study investigated the safety and immunogenicity of ETHIORAB in 12 dogs of local type.

\section{Objective}

The objective of this study is to determine whether the vaccine ETHIORAB (for veterinary use) has the required safety and immunogenicity.

\section{Materials and Methods}

\section{Study place}

The study was conducted at the Ethiopian Health and Nutrition Research Institute (EHNRI), Vaccine and Diagnostic Production laboratory.

\section{Experimental animals}

Mice: Sixteen albino mice of 3-4 weeks weighing 6-8 g, obtained from EHNRI were used for the safety study of test vaccine.

Dogs: Twelve dogs 4-5 months old, from the common local breed, were purchased, and quarantined for six weeks. They were deparasitized, vaccinated against the major canine infectious diseases (DHPPiL, CANVAC) and properly fed. The animals were then transferred to an experimentation cage.

\section{Biologicals}

Product: ETHIORAB, manufactured by Ethiopian Health and Nutrition Research Institute, which was Vero cell culture based ERA fixed rabies strain containing $1 \mathrm{IU} / \mathrm{ml}$ in a single dose, was used in this study. The vaccine was produced by multiplication of ERA rabies strain on Vero cell line grown on roller bottle. Virus harvests were clarified by filtration through $0.2 \mu \mathrm{m}$ filter and then inactivated by $5 \%$ formalin.

Standard serum: OIE Standard Serum of dog origin (OIE reference laboratory for rabies, Nancy, France) stored at $+4^{\circ} \mathrm{C}$ and diluted to $0.5 \mathrm{IU} / \mathrm{ml}$ with PBS according to the titer of the batch was used to the internal control which was used for FAVN testing.

Fluorescent Isothiocyanate Conjugate (FITC): Flourescent Isothiocyanate conjugated Anti-rabies serum (ARRIAH, Vladimir, Russia) was used for the identification of rabies virus.

\section{Fixed virus strain:}

Evelyn Rokitniki Abelseth (ERA): The ERA fixed rabies strain was kindly donated by Center for Disease Control and Prevention, Atlanta (CDC). Working seed virus was prepared from the master seed virus for the production of the test vaccine.

\section{Experimental Design}

Immunogenicity study: Random Clinical Trial (RCT) design was used for this experiment. Twelve experimental dogs from local common breed were duly conditioned during a quarantine period and assigned to two groups randomly. Group I (cases) were vaccinated subcutaneously with $1 \mathrm{ml}$ of ETHIORAB. Dogs in-group II served as non-vaccinated controls. Dogs assigned to the two groups, were bled at day zero (pre-vaccination) and at days 7, 15, 21, 30, 60, and 90 and 120 post-vaccination. Blood samples were centrifuged and sera frozen at $-20^{\circ} \mathrm{C}$ until analysed. Virus Neutralizing Antibodies (VNA) titers to rabies virus were determined by FAVN test [16]. International Reference Sera (OIE reference laboratory for rabies, Nancy, France) were used to express the results in IU/ml. Dogs with a VNA titer of $\geq 0.5 \mathrm{IU} / \mathrm{ml}$ were considered as sero converted for rabies neutralizing antibody according to WHO recommendations of acceptable sero protection [10]. All animals were rabies sero negative prior to vaccination.

Serum sample collection: Four milliliters of blood from dogs were drawn on days 0 (pre-vaccination sample), 7, 15, 21, 30, 60, 90 and 120 by a veterinarian using plain vacutainer tubes. Vacutainer tubes were labeled immediately prior to blood sample collection. The collected blood samples were left at room temperature for 30 minutes to two hours for clotting and then centrifuged at $2500 \mathrm{rpm}$ for 10 minutes to separate the sera. The serum samples were coded, and kept frozen at $-20^{\circ} \mathrm{C}$ throughout the study period.

Fluorescent Antibody Virus Neutralization (FAVN) test: Fluorescent Antibody Virus Neutralization (FAVN) test was conducted according to Cliquet et al. [16]

\section{Laboratory analysis}

Safety study: To check the presence of residual virulent virus in the vaccine mice inoculation test were done. Volumes of $0.03 \mathrm{ml}$ of the final vaccine were inoculated intracerebrally into 16 mice which were observed for 21 days. The test is satisfactory if none of the mice show any sign of rabies.

\section{Statistical analysis}

All animals that were sero negative for rabies neutralizing antibodies at baseline were included in the immunogenicity analysis. Microsoft Excel Version 2007 was used to determine the Geometric mean titers. Median lethal dose and the effective dose of CVS were calculated by Spearman-Kärber formula (WHO, 1996). GMT values were calculated on day $0,7,15,21,30,60,90$ and 120.

Calculation of immunogenicity: The $50 \%$ endpoint of the antibody $\left(\mathrm{D}_{50}\right)$ content of the sera and virus titrations $\left(\mathrm{TCID}_{50}\right)$ was calculated according to Spearman-Karber method (WHO, 1996).

\section{Ethical Clearance}

This Project obtained Ethical Clearance from Ethiopian Health and Nutrition Research Institute, Scientific and Ethical Review Committee.

\section{Results}

\section{Safety study on mice}

To check the presence of residual virulent virus in the vaccine, mice inoculation test were done. Volumes of $0.03 \mathrm{ml}$ of the final vaccine were inoculated intracerebrally in to 16 mice of age 3-4 weeks and observed for 21 days. Ruffling, partial paralysis, paralysis and death were the parameters under observation. According to the observation that we had, none of the mice showed any sign of ruffling, partial 
Citation: Hurisa B, Tegbaru B, Nolkes D, Mengesha A, Kebede G, et al. (2013) Safety and Immunogenicity of Ethiorab Rabies Vaccine. J Vaccines Vaccin 4: 195. doi: 10.4172/2157-7560.1000195

paralysis, paralysis and death. This data is in agreement with WHO recommendation for cell cultured based rabies vaccine WHO (1994) [17]. Therefore, from the experiment for safety study, ETHIORAB rabies vaccine was safe to use when $5 \%$ formalin was used as an inactivating agent.

\section{Antibody responses of dogs}

All the animals assigned to the experimental group responded to ETHIORAB rabies vaccine and developed rabies VNA. Seven days after vaccine administration the GMT of virus neutralizing antibody was $1.55 \mathrm{IU} / \mathrm{ml}$ (Figure 1). This result is better than those reported by Kallel et al. [18], in which the rabies antibody sera responded after 7 days.

Fifteen days after the administration of the vaccine the rabies antibodies response showed an increase of mean titer of VNA, the mean titer was $1.7 \mathrm{IU} / \mathrm{ml}$ (Figure 2). The result obtained at day 15 was lower than those reported by Kallel et al. [18] in which the rabies virus neutralization antibody was $6.1 \mathrm{IU} / \mathrm{ml}$ at day 15 . At 21 days post-vaccination, all vaccinated animals except one dog showed titer increase (Figure 3). At day 30, all dogs showed an increase in rabies virus neutralization antibody. Five dogs had a mean titer higher than $3.45 \mathrm{IU} / \mathrm{ml}$ at day 30 post vaccination. Figure 4 shows rabies antibody response 30 days after vaccination.

At day 60 all dogs showed a good immune response to ETHIORAB rabies vaccine with a GMT of $3.57 \mathrm{IU} / \mathrm{ml}$ and this result is the highest antibody titer response to the test vaccine Figure 5 shows the rabies

\section{Day 7}

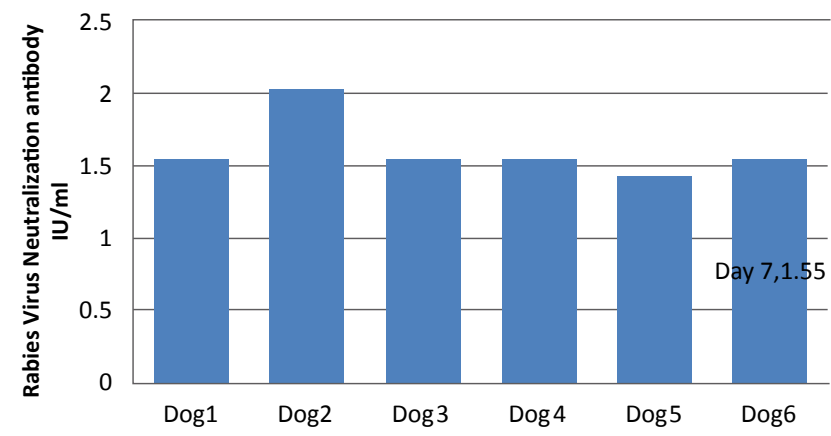

Figure 1: Rabies virus neutralization antibody response (IU/ml) day 7 after vaccination with $E T H I O R A B$ rabies vaccine.

\section{Day 15}

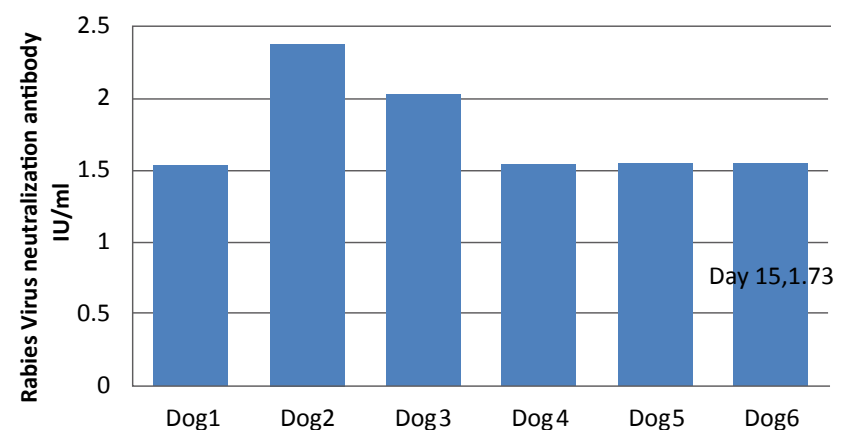

Figure 2: Rabies virus neutralization antibody response (IU/ml) at day 15 after vaccination with $E T H I O R A B$ rabies vaccine.

\section{Day 21}

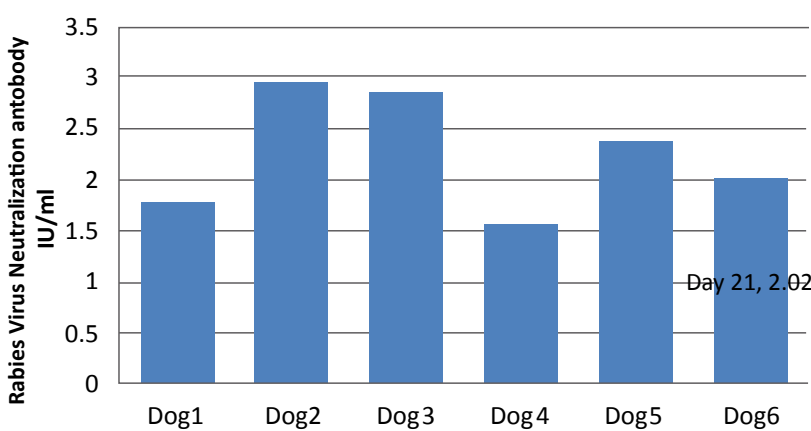

Figure 3: Rabies virus neutralization antibody response (IU/ml) at day 21 after vaccination with $E T H I O R A B$ rabies vaccine.

\section{Day 30}

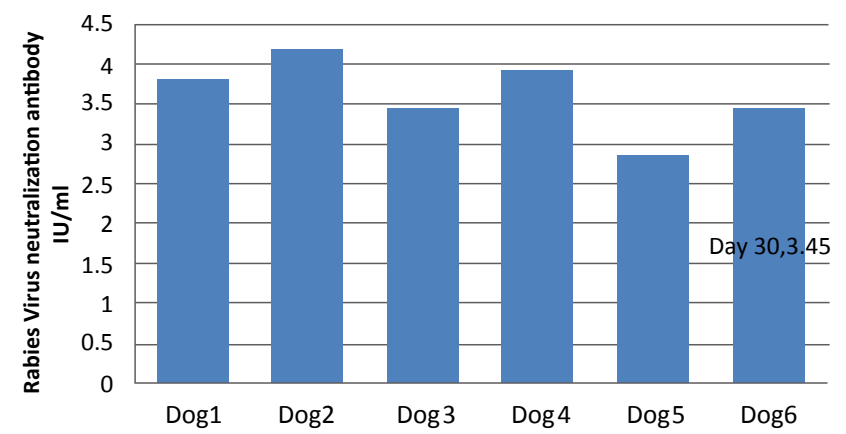

Figure 4: Rabies virus neutralization antibody to $E T H I O R A B$ rabies vaccine at day 30 post vaccination.

\section{Day 60}

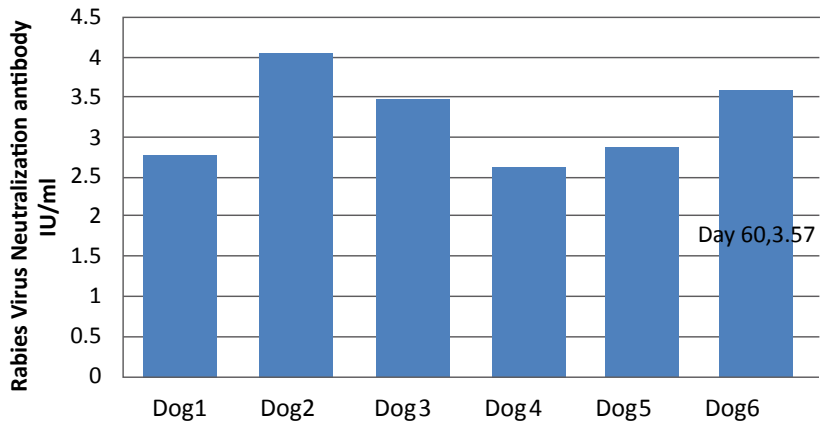

Figure 5: Rabies virus antibody response 60 days after vaccination with ETHIORAB rabies vaccine.

antibody response at day 60 . At day 90 rabies virus antibody responses declined in 2 dogs, maintained in one dog and increased in three of the dogs (Figure 6). The GMT at day 60 and 90 was $3.57 \mathrm{IU} / \mathrm{ml}$ and 3.154 $\mathrm{IU} / \mathrm{ml}$ respectively.

\section{Discussion}

In our study, all dogs vaccinated with $E T H I O R A B$ rabies vaccine showed a good immune response to rabies virus and have a rapidly 


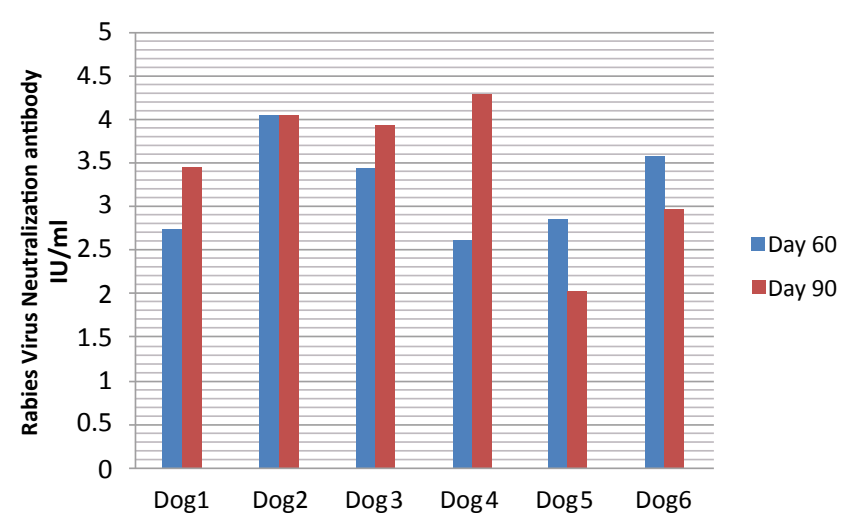

Figure 6: Rabies virus neutralization antibody response IU/mI to ETHIORAB at day 60 and 90 .

developed a high titer of rabies virus neutralizing antibodies, demonstrating that our experimental vaccine was highly immunogenic. These data were similar to Kallel et al. [18] who had done rabies vaccine in field trial on dogs. The antibody levels peaked at 30-60 days after vaccination with $E T H I O R A B$ and then progressively declined. These data were similar with those reported by Sage et al. [19] who used 26 dogs that were older than 3 months and not vaccinated.

This study was done on 12 dogs under controlled conditions to evaluate the safety and immunogenicity of cell culture based rabies vaccine produced in Ethiopian Health and Nutrition Research Institute. After vaccination with $1 \mathrm{ml}$ of ETHIORAB rabies vaccine subcutaneously, antibody titers rose rapidly as early as day 7 and all dogs had antibody titers above the WHO-recommended sero conversion threshold $(\geq 0.5 \mathrm{IU} / \mathrm{ml})$. This data is in agreement with those reported by Wang et al. [20]; Minke et al. [21] and Rio et al. [22].

Moreover, the absence of any ruffling, partial paralysis, paralysis and death after intracerebral inoculation in mice and vaccination in dogs with $E T H I O R A B$ rabies vaccine indicates that the vaccine is safe, free from extraneous agents, complete inactivation of the virus and efficiently acceptable for vaccinations against rabies in dogs. Moreover, as indicated elsewhere Monaco et al. [23], using cell cultured types vaccines are not only leading to short term therapy, but also causes an efficient immunity without contraindication or side effects.

Bahloul et al. [24] evaluated the efficiency of Rabisin vaccine in field dogs in Tunisia, and reported that at 1 month post-vaccination, the mean rabies virus neutralizing antibody titers of dogs vaccinated with the Rabisin vaccine was $4 \mathrm{IU} / \mathrm{ml}$. This study is in line with the present study and support the use of ETHIORAB vaccine in replacement of the nerve-tissue vaccines.

At day 90 rabies virus antibody response of this study vaccine started to decline in 2 dogs maintained in one dog and increase in three of the dogs, In agreement with our findings in this experiment, similar studies reported from Thailand Tepsumethanon et al. [25] showed owned dogs, vaccinated subcutaneously with a cell-culture derived vaccine, exhibited very rapidly decreased neutralizing antibody titers 60 days post-vaccination. Contradictory to this finding a study previously reported from Cameron et al. (1987), dogs primary vaccinated with either a Semple type rabies vaccine or a cell culture derived vaccine, developed a low level of neutralizing antibody and 1 month postvaccination, mean rabies virus neutralizing antibody titers were 0.37 and $0.46 \mathrm{IU} / \mathrm{ml}$, respectively. However, a booster injection after 1 year, showed that dogs immunized with cell-culture vaccine had a higher a virus neutralizing antibody titer than the animals vaccinated with the nerve-tissue vaccine (1.27 IU/ml versus $0.44 \mathrm{IU} / \mathrm{ml})$ [26-32].

\section{Conclusions}

Currently, in Ethiopia, Sheep brain derived Fermi type rabies vaccine is still being manufactured and utilized for the majority of exposed patients, even though this vaccine has been discouraged by the WHO since 1990s. Importantly, a failure rate of 0.3 to 0.8 per 1000 treated patients was reported. To solve the problem related to Fermi type vaccine, currently cell culture based anti-rabies vaccine is manufactured at Ethiopian Health and Nutrition Research Institute (EHNRI) and immunogenicity and safety procedures are studied using non-clinical study on dogs. In this study, all dogs demonstrated an extremely rapid immune response to vaccination with cell culture based anti-rabies vaccine produced for the first time in Ethiopia, within 7 days of the first injection and maintaining antibody levels over 0.5 $\mathrm{IU} / \mathrm{ml}$ for 90 days. Moreover, the safety study indicates the rabies virus is completely inactivated with $5 \%$ formalin. This indicates that a complete inactivation of the rabies virus and immunogenicity of ETHIORAB rabies vaccine. As clearly observed in this study, a single dose of ETHIORAB rabies vaccine was sufficient to envoke antibodies for a minimum of 90 days. Moreover, still after 90 days of a single immunization with ETHIORAB, neutralizing antibody titers remained greater than the minimal acceptable human level of antibody titer ( $\geq$ $0.5 \mathrm{IU} / \mathrm{ml}$ ). The measurement of neutralizing antibodies to rabies virus is commonly used to assess the level of immunity to rabies in animals. Induction of these antibodies by vaccine is a key determinant of viral neutralization and animal protection against disease development. Based on the clinical observations and serologic assay we are obtained, it can be concluded that ETHIORAB is a safe and immunogenic vaccine that could elicit the required, and even very high, antibody responses, if given subcutaneously to dogs. From the above non-clinical trial for safety and immunogenicity studies, further study is warranted to know the duration of the immunity and protectively to clinical isolates. Moreover, field trials are required before marketing or licensing.

\section{References}

1. Rupprecht CE, Hanlon CA, Hemachudha T (2002) Rabies re-examined. Lancet Infect Dis 2: 327-343.

2. Knobel DL, Cleaveland S, Coleman PG, Fèvre EM, Meltzer MI, et al. (2005) Re-evaluating the burden of rabies in Africa and Asia. Bull World Health Organ 83: $360-368$

3. Yimer E, Newayesilassie B, Tefera G, Mekonen Y, Bogale Y, et al. (2001) Situation of Rabies in Ethiopia. A retrospective study 1990-2000. Ethiopian Health and Nutrition Research Institute.

4. Deresa A, Ali A, Beyene M, Newayesilasie B, Yimer E, et al. (2010) The status of rabies in Ethiopia: A retrospective record review. Ethiop J Health Dev 24: 105-112.

5. Mebatsion T, Cox JH, Frost JW (1992) Isolation and characterization of 115 street rabies virus isolates from Ethiopia by using monoclonal antibodies: identification of 2 isolates as Mokola and Lagos bat viruses. J Infect Dis 166: 972-977.

6. Wilde $\mathrm{H}$, Tipkong $\mathrm{P}$, Khawplod $\mathrm{P}$ (1999) Economic issues in postexposure rabies treatment. J Travel Med 6: 238-242.

7. Fooks AR, McElhinney LM, Brookes SM, Johnson N, Keene V, et al. (2002) Rabies antibody testing and the UK Pet Travel Scheme. Vet Rec 150: 428-430.

8. WHO (2004) Expert Consultation on Rabies, First report. Technical Report Series, No. 931.

9. Sureau $P$ (1987) Rabies vaccine production in animal cell cultures. Adv Biochem Eng Biotechnol 34: 111-128. 
Citation: Hurisa B, Tegbaru B, Nolkes D, Mengesha A, Kebede G, et al. (2013) Safety and Immunogenicity of Ethiorab Rabies Vaccine. J Vaccines Vaccin 4: 195. doi: 10.4172/2157-7560.1000195

Page 5 of 5

10. WHO (1992) Expert Committee on Rabies, Eight report. Technical Report Series, No. 824.

11. Lodmell DL, Ewalt LC (2004) Rabies cell culture vaccines reconstituted and stored at 4 degrees $C$ for 1 year prior to use protect mice against rabies virus. Vaccine 22: 3237-3239.

12. OIE Terrestrial Manual.

13. kissling RE, Reese DR (1963) Anti-rabies vaccine Of tissue culture origin. $J$ Immunol 91: 362-368.

14. Willoughby RE Jr, Tieves KS, Hoffman GM, Ghanayem NS, Amlie-Lefond CM, et al. (2005) Survival after treatment of rabies with induction of coma. $\mathrm{N}$ Engl J Med 352: 2508-2514

15. WHO (1981) Requirements for rabies vaccine for human use. WHO Expert Committee on Biological Standardization. Technical Report Series, No. 658, Annex 2.

16. Cliquet F, Aubert M, Sagné L (1998) Development of a fluorescent antibody virus neutralisation test (FAVN test) for the quantitation of rabies-neutralising antibody. J Immunol Methods 212: 79-87.

17. WHO (1994) Requirements for rabies vaccine for veterinary use (amendment 1992) WHO Expert Committeeon Biological Standardization. WHO Technical Report Series, No. 840), Annex 6.

18. Kallel H, Diouani MF, Loukil H, Trabelsi K, Snoussi MA, et al. (2006) Immunogenicity and efficacy of an in-house developed cell-culture derived veterinarian rabies vaccine. Vaccine 24 : 4856-4862.

19. Sage G, Khawplod P, Wilde H, Lobaugh C, Hemachudha T, et al. (1993) Immune response to rabies vaccine in Alaskan dogs: failure to achieve a consistently protective antibody response. Trans R Soc Trop Med Hyg 87: 593-595.

20. Wang Y, Xiang Z, Pasquini S, Ertl HC (1998) Effect of passive immunization or maternally transferred immunity on the antibody response to a genetic vaccine to rabies virus. J Virol 72: 1790-1796.

21. Minke JM, Bouvet J, Cliquet F, Wasniewski M, Guiot AL, et al. (2009) Comparison of antibody responses after vaccination with two inactivated rabies vaccines. Vet Microbiol 133: 283-286.
22. Rio MB, Nancy B, Plebeian M, Beatriz P (2010) Safety and immunogenicity of rabies pre-and post-exposure intradermal regimens using Abhayrab, a purified vero cell rabies vaccine (PVRV) produced in India in healthy volunteers: towards greater affordability of rabies prophylaxis. Asian Biomedicine 4: 61-67.

23. Monaco F, Franchi PM, Lelli R (2006) Studies on an inactivated vaccine against rabies virus in domestic animals. Dev Biol (Basel) 125: 233-239.

24. Bahloul C, Ahmed SB, B'chir BI, Kharmachi H, Hayouni el A, et al. (2003) Postexposure therapy in mice against experimental rabies: a single injection of DNA vaccine is as effective as five injections of cell culture-derived vaccine. Vaccine 22: $177-184$

25. Tepsumethanon W, Polsuwan C, Lumlertdaecha B, Khawplod P, Hemachudha $\mathrm{T}$, et al. (1991) Immune response to rabies vaccine in Thai dogs: a preliminary report. Vaccine 9: 627-630.

26. WHO (2002) Rabies vaccines: WHO position paper. Wkly Epidemiol Rec 77: 109-120.

27. Cameron CM, Barnard BJ, Erasmus E, Botha WJ (1987) Antibody response in cattle to oil emulsion rabies and ephemeral fever vaccines. Onderstepoort $\mathrm{J}$ Vet Res 54: 157-158.

28. Dietzschold B, Faber M, Schnell MJ (2003) New approaches to the prevention and eradication of rabies. Expert Rev Vaccines 2: 399-406.

29. Hanlon CA, Kuzmin IV, Blanton JD, Weldon WC, Manangan JS, et al. (2005) Efficacy of rabies biologics against new lyssaviruses from Eurasia. Virus Res 111: 44-54.

30. Rupprecht CE, Hanlon CA, Blanton J, Manangan J, Morrill P, et al. (2005) Ora vaccination of dogs with recombinant rabies virus vaccines. Virus Res 111: 101-105.

31. Who (2007) Recommendations for inactivated rabies vaccine for human use produced in cell substrates and embryonated eggs. Technical Report Series.

32. Yusibov V, Modelska A, Steplewski K, Agadjanyan M, Weiner D, et al. (1997) Antigens produced in plants by infection with chimeric plant viruses immunize against rabies virus and HIV-1. Proc Natl Acad Sci USA 94: 5784-5788. 